\title{
INMATES, REPOSITORY OF LINGUISTIC DIVERSITY.
}

\author{
Muhammad ISHAQ \\ MPhil Scholar \\ Dr. Naima Saeed
}

Assistant Professor University of Karachi.

\begin{abstract}
This study is focused on the repository of linguistics among the inmates in district prison Quetta, the prison was established by the British regime in 1939.the large number of inmates are imprisoned in this prison, recently more than eight hundred inmates are imprisoned inside the prison, the inmates belong to different cultural and linguistic background, where they interact with one another, because the inmates live in one common barrack where they share lunch, food, clothing bathing and even they share common mod of living, the inmates in Quetta prison belong to different part of province even from all over the country, because the district prison Quetta is the most populated prison in the province, the Quetta city is the capital of province where different cultural, tribal, linguistic people are living, the major languages in the capital are Pashtu and Brahvi languages but the Hazargi, Punjabi, Seraiki, Kashmiri Sindhi and several more languages are spoken, there are several cultural traits also in the capital. Due to multilingual and multicultural context of the city the prison also has the multilingual and multicultural inmates inside the prison in Quetta, the Quetta prison also have large number of inmates from foreign countries such as Afghanistan and Iran, Bangladesh, Sudan ,turkey and many more because of several reason the foreigninmates are in the prison, because of being capital of province the district prison Quetta has several type of inmates which are
\end{abstract}


involved in different type of antisocial activities. The prison have different type of barracks where juvenile, female and male inmates are imprisoned in different barracks, the inmates not only transfer their languages but also their cultural and vocational skills. This process of skill transfer creates several type of interactions among the inmates.

Key words, Inmates, cultural and linguistic traits, imprisonment, communication,

\section{INTRODUCTION.}

This study is focused on the language repository of inmates among the prisoners in district prison Quetta, the prison was constructed by the British government before partition, there are large number of inmates, in the prisons the communication is carried out with the help of different languages especially among those prisoners who don't have knowledge regarding local languages, because good communications among the inmates and prison staff that can be through having good language skills, the large number of inmates from different cultural background make Uni-culture in the prisons (Berger, 2001). The communication problems with inmates are due to different cultural backgrounds, and the intercultural communication plays vital role in interaction between the inmates.

Intercultural and inter-lingual communication is mostly described as communication between individuals who belong to different cultural and linguistic background, (Samovar \& Porter 1976; Collier, 1989). And the culture shapes the ways through which inmates communicate, body language and gestures are type of symbolic communication, which can be perceived as aggressive or strange behavior. 
On this planet human are the only species who have the abilities of speaking, thinking and cultural activities and this is also the characteristics of human to speak more than one languages and the specific symbols for their happiness and sadness, the human societies have their own or specific language and culture due to geographicaland climate changes.

the theme of global village or globalization as in integral acceptance that the world belongs to large number of languages and cultures, as according to Ethnologies catalogue of world languages that currently 6909 living languages are in the globe but this is not conform that what is the total number of cultures in all around the world, the different geography has different cultures, the human beings have their cultures according to the climate of the area, as the climate differs from one are to another same as the culture and languages differ from place to another, but now the globalization has effected every corner and every field of life.

The demographic condition of Pakistan indicates that it's a multicultural and multilingual country, where Urdu is used as major language in the country however the official language of country is English, the provinces have different languages. The demography of Balochistan also tells that the province is multilingual and multicultural language where also Urdu is mod of instruction in province and the English is also official language in the province, the Balochi, Brahvi and Pashtu are the major languages spoken in province,

The province have different ethnic and cultural zones, the province is very much rich in cultural and having long history behind its culture, the tribes in province have protected their distinct identities, (sabir, A. R., \& Razzaq,2010), however Pashtu is speaking in all over the country and also in Afghanistan which shares border with province, and the Balochi is the other 
major language which is spoken in Pakistan and Iran, the province is long history of culture of Meher Gard civilization, the province shows large number of Archeological sites, Qazi, A. K. (2011). The tribal system in province has its strong norms and values, the cultural traits are seen in all province,

\section{THE PRISONS IN BALOCHISTAN}

The province is the largest province in Pakistan in terms of land, but the least populated province, it has scattered population the $73 \%$ land of province is mountainous due to this people mostly live in mountainous areas where livestock is the major livelihood, the strong tribal system is implemented in whole the province, the people mostly solve their issues in "JIRGAS" ( The tribal Justice system), and most of the cases are even not reported in the law courts, there is an unwritten law in tribal system which has punishment and reward, mostly the tribal chiefs solve or attend such Jirgas , the Jirga system is not only in one tribe but in all over the province, the Baloch, Pashtun and other all ethnic groups mostly solve their issues in such Jirgas which in the legislation of country these are not accepted legallyKhan, A. (2009). As they believe that the Jirga system does not allow for abusive practices and the Jirga or tribal system prohibits the people not to commit crimes, the tribal system is also one social force to stop the people for violating the cultural norms.

As the province has the lowest population in Pakistan according to census department the province has $6.85 \%$ population as compare to whole population in country, due to its low population, the population in prisons is also low as compare to other provinces, but however the tribal system is the major cause behind the low population in prisons, Ghaffar, N. (2012). 
However the crime rates had been increases in last few year due to political unrest in the province which caused high population in the prisons.

The prison are places where inmates are involved in the criminal offences and they are detained for punishment, the present shape of prisons is invention of $19^{\text {th }}$ century, the aim of prisons is to rehabilitate the offenders who are involved in anti-social activities,

(Scott \&Gerbasi, 2005). And in the $16^{\text {th }}$ and $17^{\text {th }}$ century the prisons were used to detain those who were involved in different criminal activities and physically they were punished in order to quit that criminal behavior and to refrain others not to commit crimes or not to be involved in anti-social activities (Howard League of Penal Reform, 2005). But in modern societies the concept of imprisonment is changed in the developed countries the prisons are totally rehabilitation center where inmates are facilitated different type of psychotherapy in order to remove the criminal behavior the inmates are given different type of vocational trainings in order that they can become reliable citizen in the society,

There are eleven prisons in Balochistan in which five district prisons and six central prisons are included,currently some 3300 inmates are imprisoned in these prisons, the large number of prisons are established by the British government but now the prison department is a provincial subject and all the policies and laws are framed at provincial level, prisons are considered as institution were inmates are facilitated with the facilities are programs to rehabilitate them, in the prison there are different type of inmates in the prison such as male, women, and juvenile offenders, the prison such as central prison Mach where just convicted prisoners are kept from all over the country, but however the other prison have convicted and under trail prisoners also, such as district prison Quetta where several type of prisons are 
kept, the District prison Quetta has from petty crime to major criminals inside the prison, as there are no industries in the prisons in Balochistan due to that mostly prisons spend their time while getting together for different purpose

The district prison Quetta was established in 1939 in the British colonial era, the prison has different barracks for the inmates, there is one women barrack and one barrack for the juvenile offenders and twelve other barracks including one barrack for high profile prisoners, there is basic health unit available for the prisons, recently more than eight hundred prisons are imprisoned, several type of prisoners are kept in the prison, the prison.

In the District prison Quetta, they prisoners belong to different ethnic groups, they have different language and culture, which they share to one another, the prisoners share their vocational skills also such as the beads works are very much famous in the prison and this skills has been transferring for many decades, even form one prison to other, in the same way the prisoners also share their language, as there are case histories that foreign prisoners have learnt local languages in the prison and recently there are many foreign prisons in the district prison Quetta, where the prisoners from Sudan can fluently speak Balochi language as they have learnt it in Central prison Gadani from the Baloch inmates, as is the case in the district prison Quetta, where prisoners from Afghanistan, Najera, Bangladesh and many other countries could speak local languages fluently.

\begin{tabular}{l|l|l|l} 
S/NO & PROVICNE & FREQUENCY & PERCENTAGE \\
\hline $\mathbf{1}$ & BALOCHISTAN & 223 & $61.5 \%$ \\
\hline $\mathbf{2}$ & KPK & 27 & $\mathbf{1 3 \%}$ \\
\hline 3 & SINDH & 18 & $\mathbf{9 \%}$ \\
\hline $\mathbf{4}$ & PUNJAB & 29 & $\mathbf{1 5 \%}$ \\
\hline $\mathbf{5}$ & AJ\&K & $\mathbf{3}$ & $\mathbf{2 \%}$ \\
\hline & TOTAL & 300 & $\mathbf{1 0 0 \%}$
\end{tabular}


The above table shows that major number of prisoners belong to Balochistan province but however the table also shows the prisoners from all over the county including Azad Jammu and Kashmir, the inmates from all the country can share their languages and culture to one another, because the inmates share common barrack, where they spent their twenty four seven, which causes them to learn their language and share their cultural traits

\begin{tabular}{l|l|l|l} 
S/NO & NATIONALITY & FREQUENCY & PERCENTAGE \\
\hline 1 & PAKISTANI & 200 & $67.0 \%$ \\
\hline 2 & AFGHANI & 85 & $28 \%$ \\
\hline 3 & BANGLADESH & 5 & $2 \%$ \\
\hline 4 & NIGERIA & 3 & $1 \%$ \\
\hline 5 & IRAN & 7 & $2 \%$ \\
\hline & TOTAL & 300 & $100 \%$
\end{tabular}

The above table shows that the prisoners from different neighboring countries are imprisoned in the Quetta district prison, as Balochistan shares long border with Afghanistan and also large number of afghan refugees are living in the province, the large number of illegal afghan nations are imprisoned in the prison. Same as the case because province shares large costal area where different type of inmates from the several neighboringcountries are arrested while being involved in illegal activities such as smuggling is the most famous act which is mostly acted by the foreigners, the foreigner prisoners also share their culture and language with local inmates and also learn the local culture and languages which are spoken in the prisons.

\section{THE PRISONER'S TYPE.}


As mentioned above there are different type of prisoners at district prison Quetta the following table shows the types of prisoners who are imprisoned at district prison Quetta.

\begin{tabular}{l|l|l|l} 
S/No & Prisoner's Type & Frequency & Percentage \\
\hline 1 & Under Trail & 145 & $48.3 \%$ \\
\hline 2 & Convicted & 106 & $35.2 \%$ \\
\hline 3 & Detainee & 49 & $16.4 \%$ \\
\hline & Total & 300 & $100 \%$
\end{tabular}

\section{PRISONERS MOTHER TONGUE.}

As mentioned before the diversity of languages is noticed in all prisoners in district prison Quetta, the respondents live together where they share common barrack, bathroom, living area, food, and etc.where they share their social and cultural norms, the aim is to know the diversity of languages among the prisoners where they respondents are asked to show their mother tongue that researcher can come to know about their primary or first language which they speak at home.

The following table shows the mother tongue of respondents

\begin{tabular}{l|l|l|l} 
S/No & Mother Tongue & Frequency & Percentage \\
\hline 1 & Sindhi & 18 & $4.0 \%$ \\
\hline 2 & Pashto & 142 & $47.3 \%$ \\
\hline 3 & Baloachi & 9 & $3.0 \%$ \\
\hline 4 & Brahvi & 49 & $16.3 \%$ \\
\hline 5 & Hazargi & 88 & $29.3 \%$ \\
\hline 6 & Seraiki & 17 & $6 \%$ \\
\hline 7 & Persian & 11 & $4 \%$
\end{tabular}




\begin{tabular}{l|l|l|l}
8 & Bengali & 7 & $2 \%$ \\
\hline 9 & Swali & 3 & $1 \%$ \\
\hline & Total & 300 & $100 \%$
\end{tabular}

The above table show that there are several type of languages spoken inside the district prison Quetta, because the respondents have different local and foreignlanguage.

\section{INTERACTION BETWEEN THE RESPONDENTS.}

Though it is not easy to live together or to create healthy and peaceful environment at prisons where prisoners belong to different social, cultural and background characteristics, the prisoners spend their major time together because of living in one boundary and one barrack, they share their views and daily activities or the visits by the relatives, the respondents discuss their legal aid and legal hearing with one another, the respondents have no facilities of entertainment, the major barracks even do not have the facility of television, the respondents don't get daily newspaper on daily bases but however while getting these information's from their visitors, later they share these all with discussions with their mates,

\section{RESPONDENTS LEISURE TIME ACTIVITIES.}

Due to multilingual and multicultural the respondents share different type of leisure activities with one another, the respondents also belong to different geographical areas where they share different type of activities where they interact with one another and also pass their time while playing several type of indoor games such as Ludo and playing card but the locally game played "KATTAR" is also very much famous inside the prison and that does not need some especial instruments for playing. 


\section{LANGUAGE DIVERSITY AMONG THE PRISONER'S.}

While conduction this study the language diversity is noticed among the responders, as mentioned above due to living under one common roof the respondents share their language, social and cultural characteristics, according to this study the Pashto and Brahviare the dominant and common languages at district prison Quetta and there the different accent of Pashto is spoken because the respondents from KPK province have their especial and specific accent in speaking but other Pashtun respondents who belong to Balochistan and Afghanistan their accent is different than those but however the Pashto language is spoken by both the causes of Pashtu language dominancy is because the respondents who belong to Hazara community, Baloch community or Sindhi community they can speak Pashto fluently due to market language also however accept this the second common language is Brahvi which is spoken by many other those whose primary language is not Brahvi, mostly Sindhi and Balochi speaking respondents speak Brahvi as second language, and these respondents also can speak Pashto and Hazargi, those respondents whose primary language is Brahvi they also can speak Pashto, Persian, Balochi and even Hazargi fluently due to diversity in their languages and spending major time with each other, it is also observed in the study that the foreignrespondents even can speak local languages.

The following table shows the frequency and percentage of respondents who are bilingual or even multilingual.

\begin{tabular}{l|l|l|l} 
S/No & Languages & Frequency & Percentage \\
\hline 1 & Monolingual & 57 & $19 \%$ \\
\hline 2 & Bilingual & 149 & $50 \%$
\end{tabular}




\begin{tabular}{l|l|l|l}
3 & Multilingual & 94 & $31 \%$ \\
\hline Total & 300 & $100 \%$
\end{tabular}

The above table shows clearly that major percentage of respondents are bilingual and also huge percentage of respondents are multilingual the only $19 \%$ respondents are monolingual, 


\section{$\underline{\text { References }}$}

(1) Sheikh, K. H., \&Arif, G. M. (1989). An Analysis of Rural Homelessness inPakistan. The Pakistan Development Review, 28(4), 925-935.

(2) Mahmood, S., Sheikh, K. H., Mahmood, T., \& Malik, M. H. (1991). Food,Poverty andits Causes in Pakistan [with Comments]. The Pakistan Development Review, 30(4), 821-834.

(3) Sawada, Y., \&Lokshin, M.(1999). Household schooling decision in rural,Pakistan.World Bank Policy Research Working paper, (2541).

(4) Cekaite, A., \&Björk-Willén, P. (2013). Peer group interactions in multilingual educational settings: Co-constructing social order and norms for language use. International Journal of Bilingualism, 17(2), 174-188.

(5)Ahasan, M. R., \&Partanen, T. (2001). Occupational Health and Safety in the Least,Developed Countries-A Simple Case of Neglect. Journal of epidemiology, 11(2), 74-80.

(6) Kawakami, T., \&Kogi, K. (2001). Action-oriented support for occupational safety and health programs in some developing countries in Asia.International Journal of Occupational Safety and Ergonomics, 7(4), 421434.

(7)Woolard, K. A. (1989). Sentences in the language prison: The rhetorical structuring of an American language policy debate. American Ethnologist, 16(2), 268-278.

(8)Husain, F., Qasim, M. A., \& Sheikh, K. H. (2003). An analysis of publicexpenditure on education in pakistan. The Pakistan development review,42(4), 771-780.

(9)Ross, M. H., \& Murray, J. (2004). Occupational respiratory disease in mining. Occupational Medicine, 54(5), 304-310.

(10)Donoghue, A. M. (2004). Occupational health hazards in mining: anoverview. Occupational Medicine, 54(5), 283-289.

(11)Rickford, J. R. Language Diversity and Academic. Language and Readem, 13. 
(12) Memon, G. R. (2007). Education in Pakistan: The key issues, problems and the new challenges. Journal of Management and Social Sciences, 3(1), 47-55.

(13)De Klerk, V., \&Barkhuizen, G. (2001). Language usage and attitudes in a South African prison: Who calls the shots?. International journal of the sociology of language, 97-116.

(14)Baugh, J. (1999). Considerations in preparing teachers for linguistic diversity. Language and Readem, 92.

(15)Malik, N., Maan, A. A., Pasha, T. S., Akhtar, S., \& Ali, T. (2010). Role of hazard control measures in occupational health and safety in the textile industry of Pakistan. Pak J AgriSci, 47(1), 72-76.

(16)urRehman, H., Faridi, M. Z., \& Bashir, F. (2010). Households saving behavior in Pakistan: A case of Multan district. Pakistan Journal of Social Sciences (PJSS), 30(1), 17-29.

(17)Awan, S., Nasrullah, M., \& Cummings, K. J. (2010). Health hazards, injury problems, and workplace conditions of carpet-weaving children in three districts of Punjab,Pakistan. International journal of occupational and environmental health, 16(2), 113-119.

(18)Sabir, A. R., \&Razzaq, W. Multiculturalism:

(19)Akram, W., Naz, I., \& Ali, S. (2011). An Empirical Analysis of Household Income in Rural Pakistan: Evidences from Tehsil Samundri. Pakistan Economic and Social Review, 231-249.

(20)Malik, M. S., Basit, A. B., \&Qazi, A. K. (2011). Unions and Management: A Case Study of Pakistan Telecommunication Corporation. Pakistan Journal of Social Sciences (PJSS), 31(1), 185-199.

(21)Hassan, S. A. (2012). Health, safety and environmental practices in the construction sector of Pakistan. 